International Journal of Biological Research, $2(2)(2014)$ 149-152
International Journal of Biological Research
Journal home page: www.sciencepubco.com/index.php/IJBR
doi: $10.14419 /$ ijbr.v2i2.2440
Research Paper

\title{
Tourism and resource development: a case study of Madhya Pradesh
}

\author{
Devendra N. Pandey ${ }^{1}$, Satyendra Kumar Mishra ${ }^{2}$, Sandeep Kumar Shukla * $^{3}$ \\ $1 \& 2$ Department of Zoology Govt. S.K.N. P.G. College, Mauganj, Rewa (M.P.) \\ ${ }^{3}$ Department of Zoology Govt. Maharaja (P.G.) College, Chhatarpur (M.P.) \\ *Corresponding author E-mail: sandeepshukla910@gmail.com
}

\begin{abstract}
At present tourism is considered as one of the important economic sector, which impels the growth \& development of many of the states of India. Tourism provides a marketable product, which does not depend on raw materials from outside. This paper analyses the problems \& strategies for tourism and resource development, which bears great prospects in future development of Tourism. Hospitality, the foundation on which the edifice of Madhya Pradesh tourism built, is indigenous to Madhya Pradesh. Madhya Pradesh sends largest number of travellers to almost every corner of the world, but its strengths to be host is not yet been fully utilized due to the lack of information highway. Madhya Pradesh is also known, as the "Heart of India". It offers colourful experience to its travellers packed with pleasant surprises, endowed with forest \& deserts, hills \& plains, \& lakes, tribal hinterlands \& special interest destination with a strong rail, road, \& air network. The Poor infrastructure, ineffectual marketing \& inefficient management of resource ensures that tourist steer clear, little wonder then, Madhya Pradesh contribute little over $2 \%$ to the total tourist traffic of the country, while neighbouring Rajasthan share is over $4 \%$. The Government policies has been introduced to eradicate the problems associated, but still it is on the paper \& will have to travel far long way to reach their destinations. Most of tourism planning in the region appears to be adhoc. Therefore, it is essential to move away from such an ad hoc approach to draw up definite plans of action, charting out the future directions clearly.
\end{abstract}

Keywords: Tourism, Resource Development, Eradication, Hospitality and Infrastructure.

\section{Introduction}

The Tourism is the fastest growing industry in the world, and more so in the eastern hemisphere of the globe. About 600 million tourists go globe-trotting every year, of which India receives only 2.30 million, yet it stands as the third largest foreign exchange grosser for the country (Dr. A. Satish Babu). The concept of tourism differs among the people of various branches. Tourism is the act of travel for the purpose of recreation and business, and the provision of services for this act. Tourists are people who are "traveling and staying in places outside their usual environment for not more than one consecutive year for leisure, business and other purposes not related to exercise of an activity remunerated from within the place visited" (official UNWTO definition). The distance between these two places is of no significance. Sometimes Tourism and Travel are used interchangeably. In this context travel has a similar definition to tourism, but implies a more purposeful journey. In 1976 Tourism Society of England defined it as "Tourism is the temporary, short-term movement of people to destination outside the places where they normally live and work and their activities during the stay at each destination. It includes movements for all purposes."

A more comprehensive definition would be that tourism is a service industry, comprising a number of tangible and intangible components. The tangible elements include transport systems- air, rail, road, water, vegetation (forest) and now, space; hospitality services- accommodation, foods and beverages, tours, souvenirs; and related services such as banking, insurance and safety and security. The intangible elements include: rest and relaxation, culture, escape, adventure, new and different experiences. "Tourism is the temporary movement of people to destinations outside their normal places of work and residence, the activities undertaken during their stay in those destinations, and the facilities created to cater to their needs" (Mathieson \& Wall, 1982).

During their stay in the destination, tourists interact with local residents and the outcome of their relationships is, the changes in the host individual's and the host community's quality of life, value systems, labour divisions, family relationships, attitudes, behavioral patterns, ceremonies and creative expressions (Fox, 1977; Cohen, 1984; Pizam \& Milman, 1984), interaction of tourists do not ends here, rather it has multi-facet and has its implication on the natural surroundings as well. It is a major sociocultural phenomena of the new age society $\&$ is related with economic mobility and thereby several consequences. However, the movement of people to the places of interest was there since time immemorial but was without commercial approach \& organizational \& managerial skill. Tourism, in today's context, is considered to be a virile instrument of economic development \& employment generation for both educated $\&$ uneducated masses.

Objectives The main objectives of this study:

1) To find out the function of resources in the tourism development

2) To study of problems associated with development of tourism on resources and strategies for their management. 


\subsection{Data base \& methodological framework}

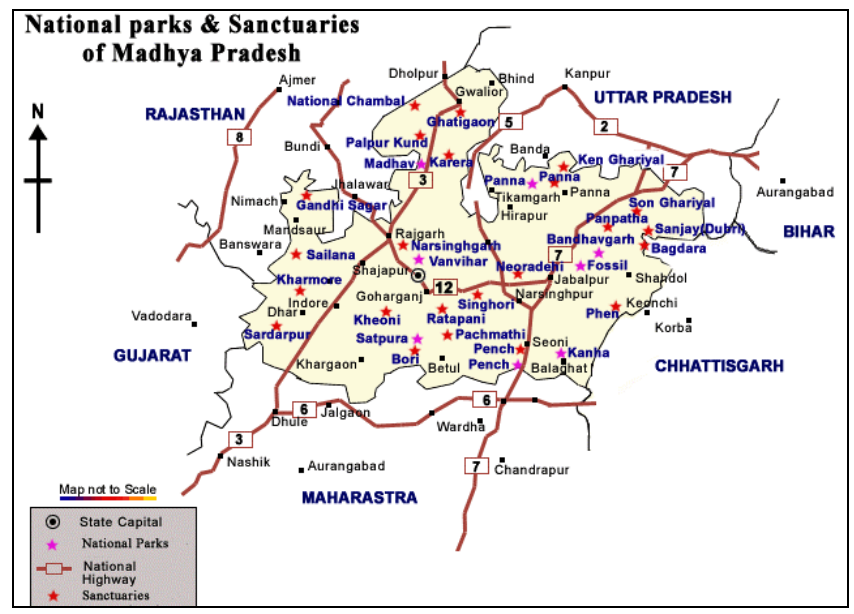

The study is based on the personal observations \& available secondary sources. The secondary sources includes the reports provide by Madhya Pradesh Tourism Corporation Limited (MPTCL), various articles at state, national $\&$ international level. Now days the places of natural surroundings are becoming a major attraction for tourists interests, because of its pure natural values. The tourist as observer, have a significant role in changing pattern of utilizing the resources \& bringing the spatial variation in it over a region, which have direct or indirect influence on tourism environment. In this viewpoint, the present attempt has been generalized to understand the impact of environment on tourism development.

\section{Study area}

Madhya Pradesh literally means "Central Province", and is located in the geographic heart of India, between latitude $21.2^{\circ} \mathrm{N}-26.87^{\circ} \mathrm{N}$ and longitude $74^{\circ} 02^{\prime}-82^{\circ} 49^{\prime}$ E. The state straddles the Narmada River, which runs east and west between the Vindhya and Satpura ranges; these ranges and the Narmada are the traditional boundary between the north and south of India. The state is bordered on the west by Gujarat, on the northwest by Rajasthan, on the northeast by Uttar Pradesh, on the east by Chhattisgarh, and on the south by Maharashtra.

Madhya Pradesh has a subtropical climate. Like most of north India, it has a hot dry summer (April-June), followed by monsoon rains (July-September) and a cool and relatively dry winter. The average rainfall is about $1,370 \mathrm{~mm}$ (53.9 in). It decreases from west to east because monsoon wind moves from west to east and drained clouds in western part takes less quantity of water vapours with them to eastern part. The south-western districts have the heaviest rainfall, some places receiving as much as $2,150 \mathrm{~mm}$ (84.6 in), while the western and north-western districts receive $1,000 \mathrm{~mm}$ (39.4 in) or less.

Since the study area is not concentrated to any particular place or point but Madhya Pradesh as a whole. The current world tourism contribution to GDP is $11 \%$, while, Indian tourism contribution to GDP is $1.8 \%$ and it is targeted to reach $6 \%$ in the next decade. If this can be re-targeted to reach $10 \%$, an additional 1.2 crore jobs can be created. A majority of the 2 crore NRIs, are central Indian who are prosperous as professionals and traders. This untapped resource can be motivated to become prospective tourists and investors in this sector and the GDP level can be improved considerably. The state of Madhya Pradesh has been transformed into an industrial powerhouse during the last three decades reducing its dependence on agriculture and textiles.

\subsection{Development of Madhya Pradesh tourism}

Madhya Pradesh has a long historical and cultural tradition dating back to the days of the Harappa civilization established by relics found at Lothal. Situated on the central part of the India. Tourism is one of the most important sectors in Madhya Pradesh, which is to be exploited in the coming years. The Madhya Pradesh tribal life is a celebration, of music, dance and multi-coloured traditions. Activities like religious and archeological tourism, heritage, coastal and beach tourism, adventure tourism, highway tourism etc are being encouraged. The State thus offers scope for investment in tourism related activities in the form of accommodation projects, food oriented projects, amusement parks and water sports, handicraft village complexes, sea/river cruise, safari project, sports/health facility complexes, etc. The Government would also like to encourage service-oriented projects like travel operation, tour operation, transport operation etc. Madhya Pradesh has a long varied history and a great number of interesting places to visit. Some of the most important sites in Madhya Pradesh are scenic beauty, national parks, wildlife sanctuaries as a Khajuraho temple, Panna Tiger Reserve, Khana National Park, Bandhav Garh, Sone crocodile sanctuary etc. The tourism policy in India provides boost to the tourism industry in order to harvest the socio-economic benefits of this service providing sector. The ministry of tourism in the year 2004 has launched the "Atithi Dev Bhav", "Guest is God" \& is the latest key to the Indian tourism sector, in order to attract a fairly good chunk of tourists both local as well as international. Similar type of promotional movement can be seen in almost all the states as for example, "Madhya Pradesh, where life is celebration" is the new mantra of the Madhya Pradesh state tourism corporation \& has declared the year 2006 as tourism year to promote tourism in Madhya Pradesh.

\section{Tourism \& resource development}

According to Prof. Zimmerman, Resource does not refer to a thing or substance but to a function which thing or substance may perform or to an operation in which it may take part"e. The significance of the term tourism \& resource relationship can be understood by economic geographer as resource is neither a material nor substance but a positive interaction between man \& nature, positive in terms of satisfying individual needs \& social objectives that we may apply for tourism development. Tourism and resource both are interrelated. Tourism helps in upgrading the quality of resources, which has not yet been fully utilized. Say for example most the hills \& mountains are remain virgin i.e. not been touched by the human beings, because of prevailed inaccessibility, can be developed as a hill tourism or mountain tourism, such as adventure, climbing, tracking, hill station tourism etc. The plain has now become the hub of all cultural development; in fact we can say it possesses the world's best-developed potential tourism environment in the world. Now the new type of tourism is coming in view i.e. the forest $\&$ wildlife tourism, which has catered a huge number of tourists from all over the world, because of its natural environment. In M.P. such places are Khajuraho, Panna National Park. Khana National Park, Ken and Sone Crocodile sanctuary, Bandhav Garh National Park major national parks and sanctuary. Tourism has the potential to create beneficial effects on the resource development by contributing to environmental protection and conservation. It is a way to raise awareness of environmental values and it can serve as a tool to finance protection of natural areas and increase their economic importance. The quality of the environment, both natural and man-made, is essential to tourism. The impact of tourism on the land environment can be seen in the form of sprouting hotels restaurants, \& others kinds of related infrastructures, which fulfills the demand of the tourists. Rise of cultural landscape in the form of nature park natural reserves, parks, golf courses etc. transforms the natural landscape. In short complete land use pattern alter in the places of tourists interests. Gossling (1999) suggests that nature-based tourism is derived from the existence of natural areas with no specific concern for their protection, whereas ecotourism is concerned with the protection of natural areas mostly to achieve rural economic development by enabling people who live in rural areas to capture the economic nonuse values derived from natural areas. Typical ser- 
vices offered at ecotourism destinations might include local arts and crafts, guided hikes and wildlife viewing, publications, natural history lectures, photography, and local food. Revenues are generated from fees for these services, as well as natural area user fees and local expenditures for hotels, restaurants and bars, and transportation services (Seidl 1994). Some writers qualify ecotourism even more specifically, suggesting that it also must provide direct revenue toward the conservation or protection of natural areas and educate tourists about related environmental issues. The Ecotourism Society defines ecotourism as "travel to natural areas to understand the cultural and natural history of the environment, taking care not to alter the integrity of the ecosystem, while producing opportunities that make the conservation of the natural resources beneficial to local citizens" (Wood 1993). The qualification that ecotourism not harm the natural environment raises the issue of sustainability and the additional concept of sustainable tourism. Sustainability in tourism literature can be considered within political, social, economic, ecological, and cultural contexts (Henry and Jackson 1996) with sustainability of natural resources being the predominant view. Ecotourism precludes more intensive exploitation of natural resources in rural areas or developing countries by providing economic returns that exist as positive incentives to local residents who are enlisted in natural resource protection. In this view, non-tourism industries generally are portrayed as exploitative and degrading to natural resources, whereas tourism generally, and ecotourism specifically, are advocated as ways to capture natural resource use and nonuse values. According to this view, non-tourism industries must be controlled and ecotourism promoted. Some researchers view the tourism industry itself as exploitative and degrading to natural resources as well as indigenous people and cultures. According to this view, the development of tourism is what must be controlled to sustain natural resources and cultural attributes on which tourism depends.

\subsection{Constraints associated with tourism resource devel- opment}

Madhya Pradesh is one of the premiers commercial \& industrial states, has recognized tourism to be a major thrust area for economic growth in the state. The Govt. of Madhya Pradesh realized the potential of tourism wealth creation \& employment generation. In 2011-12, Madhya Pradesh is one of the state which received one the highest international tourists and ranked 6th among all the states of India. This situation was very worst during 2011 where it was ranked 17th among all the states. There was marginal increase of tourists in Madhya Pradesh during 2009, thereafter it has gone worst in 2012 i.e. $0.25 \%$ of the total tourists in India. In 2005, when the Govt. of Madhya Pradesh has realized its potential resources \& made some valuable policies to attract tourists internationally, nationally as well as locally \& it has achieved also $(0.47$, table). Now days the MPTCL is concentrating more to locate only the foreign tourists, this is the major drawback for the tourism development. "We don't consider the person as tourists who arrive here whether he is from foreign countries or localized, do not stay in the hotels. It shows that in Madhya Pradesh the domestic tourism has not gain much importance than international tourism. This is the main region the people of Madhya Pradesh move to other states such as Rajasthan, Maharashtra, and Gujarat etc. to spend their holidays. Nearly 63 per cent of the 1.14 crore (11.4 million) domestic tourists visiting the state every year are Madhya Pradesh while the rest are mostly on pilgrimage tourism, Kishore Rao said. But still, more than 50\% of Madhya Pradesh moves to other states mostly to Gujarat. Paradoxically however, growing recognition of the importance of travel and tourism by the Govt. of Madhya Pradesh, there seems to be a lack of appreciation of its scope, complexity, \& dynamism. This industry works beyond local boundaries at global level bringing together diverse industries. The Govt. of Madhya Pradesh should inculcate this appreciation of travel and tourism industry to obtain long-term gains for the state. The urgent need for the Govt. of Madhya Pradesh is to view the tourism in a holistic sense, beyond its national \& global boundaries bringing together the internal dynamic elements like its stakeholders-the community the private sector to work towards a tourism concept that benefits all \& retains tourism assets for future. In the development of tourism environment the local participants plays a very important role, because these people are well aware of their local availability of resources. The Government level organizations cannot world alone without taking consideration the local level. The gap between these two level is high in Gujarat. There is a need of some Semi-Governmental organizations, which can provide the required information about the area or place. The lack of proper knowledge of the places of interests, the guide's misguide the tourists in fake of just making the money from them, because of this the tourist get bored \& don't take interest. They also charge very high per hour from tourists.

\subsection{Some basic problems associated with foreign tour- ists in Madhya Pradesh}

A foreigner might be gaped at and fawned over almost everywhere in the state, but he is treated in a most unfair manner when it comes to paying tourist tariffs. In Madhya Pradesh, a foreign visitor has to pay almost eight and in some cases 25 times more than an Indian tourist. Although the Union government is now planning to end the discriminatory regime across the country, in Madhya Pradesh it will take much more than that to boost tourist traffic. For instance, the entry fee at Panna Tiger Reserve for a foreigner (adult) is $\$ 5$, while it is just Rs 30 for Indians. If a foreigner wants to carry a camera, it will cost him another $\$ 5$ while an Indian has to pay Rs 50. A foreigner would have to shell out $\$ 200$ for shooting amateur video and $\$ 1,000$ for a feature film.

An Indian will have to pay Rs 2,500 and Rs 20,000 respectively. Hotel and food costs are higher too. For foreigners, AC rooms would cost \$ 50 and for Indians Rs 1,000. The dominance of these problems we are losing the number of tourists apart from other continents, which become a big hindrance in the tourism development in Gujarat. Apart from differential tariffs, the state has a whole lot of other disadvantages. Poor infrastructure, ineffectual marketing and inefficient management of resources ensure that tourists steer clear. The cumulative effect is that tourist traffic seems to be falling in the state. According to Madhya Pradesh Industrial \& Technical Consultancy Organization (MPITCO), which collates tourist data in the state, number of foreigners has actually dropped in the past two years. In 2010-11, 37,252 foreigners visited the state, which dropped to 31,271 in 2011-12 and to 21,567 in $2012-13$. But tourism officials say that the data was incorrect. "MPITCO has been collecting figures only from hotels. We have directed it to get data from airlines too," an official claims. After the changes were made, the MPITCO data between 2012 April and December shows number of foreigners shot up to 48,020 . While the government dithers on exact tourist data, observers say, it must get its act together and develop a sound tourism policy. We will have to look at fundamental issues hampering tourist traffic in the state, one of which is poor marketing". "The revision in tariff structure will encourage more foreigners to come to the state. But that is not it - physical resource has to be improved and tourist sites need to be better managed," says head of master program in urban design at Centre for Environmental Planning \& Technology (CEPT). Apart from these problems the interference of politics, is the biggest obstacle for the tourism development, which are very common in all governmental organizations. The waste of money behind unnecessary expenditures is another drawback in the tourism sector \& in the hotel industry. This is a time to the globalization where we need highly trained, experienced, efficient, intelligent \& dynamic professionals. We earn more money \& reputation at the cost of hard work. There is much to be done. If tourism development is not taken up with some urgency and in a planned manner it is quite possible that instead of tourism providing an economic push, in a liberalized atmosphere, the region may suffer from a reverse flow. In tourism, as elsewhere, if the goods cannot meet the competition, the outflow may overtake inflow. 


\section{Tourism resource management strategies}

Maintaining the natural resource power planning \& getting the result in the tourism corporation is a challenging task for Madhya Pradesh Govt. due to inefficient human resource as well as planning techniques. The attempts have been made to provide the management strategies \& planning techniques to maintain the sustainability, they are follows: -The semi-governmental organizations would work more in the needed areas of tourism development, because of their knowledge about people behaviour as well as local resources because they are more mingled with local people as well as the local resources. This sort of management will have the following advantages as compared to the governmental system:

- The freedom to utilize foreign funds.

- The ability to experiment freely with innovative approaches.

- Flexibility in adapting to local situations and responding to local needs.

- Good rapport with people and ability render micro-assistance to very poor people as they can identify those who are most in need and tailor assistance to their needs.

- The ability to communicate at all levels, from the neighborhood to the top levels of government.

- The ability to recruit both experts and highly motivated staff with fewer restrictions than the government.

- The tourist places which comes under the forest department should carries out the following regular activities to maintain ecotourism-

- Protection of the legally declared forest areas from misuse by the public.

- Protection of the wildlife from getting poached.

- Developing and managing eco-friendly tourism in the forest areas.
- Implementing alternate income generation activities for the forest dependent people.

- Conservation education programs for various target groups like school and college students.

- Design, printing and distribution of information brochures, booklets etc. among the public to create environmental awareness.

\section{Conclusion}

From the above study it can be said that the growth of economy generated by tourism industry would affect positively to all levels of people, not only at higher level but also to local level, which may help in improving their social economic conditions \& will results in balance growth. The proper planning and management techniques definitely will play a key role in improving the standard of living of people who are dependent on the tourism. The Gujarat endowed with plenty of resource (both physical \& human resource), which must be utilized in a sustainable manner. The state should give importance to the concept of eco-tourism \& development of nature based tourism rather than setting up the environment exhaustive economic activities. The encouragement of private sectors to enter in this field would definitely make a lot of difference in managing the available tourism resource. Only just capital investments will not help in development but the local people participation is also required. The various institutions working in this field should undertake the long term planning methods to develop the region. The Madhya Pradesh being a sovereign of almost all type of potential resource, it has great future prospect in the tourism development.

Table 1: State wise Foreign Tourist Visits in India (Major States) (2007-2012)

\begin{tabular}{|c|c|c|c|c|c|c|}
\hline STATE & 2007 & 2008 & 2009 & 2010 & 2011 & 2012 \\
\hline Andhra P. & 78713 & 67147 & 210310 & 479318 & 501019 & 78713 \\
\hline Bihar & 73321 & 85673 & 112873 & 60820 & 38118 & 73321 \\
\hline Goa & 291709 & 260071 & 271645 & 314357 & 363230 & 291709 \\
\hline Haryana & 1113 & 898 & 85281 & 84981 & 66153 & 1113 \\
\hline Himachal P. & 111191 & 135760 & 144383 & 167902 & 204344 & 111191 \\
\hline $\mathrm{J} \& \mathrm{~K}$ & 19400 & 21298 & 7821 & 24330 & 40242 & 19400 \\
\hline Karnataka & 208000 & 140703 & 59545 & 249908 & 530225 & 208000 \\
\hline Madhya P. & 1075169 & 107824 & 67319 & 92278 & 145335 & 1075169 \\
\hline Maharashtra & 111036 & 915399 & 768935 & 986544 & 1218382 & 111036 \\
\hline Rajasthan & 623100 & 608283 & 428437 & 628560 & 971772 & 623100 \\
\hline Tamilnadu & 785876 & 773073 & 804041 & 901504 & 1058012 & 785876 \\
\hline Uttar P. & 848000 & 795000 & 710000 & 817000 & 1037243 & 848000 \\
\hline West Bengal & 197061 & 284092 & 529366 & 705457 & 775694 & 895639 \\
\hline INDIA & 5893542 & 5436261 & 5157518 & 6708479 & 8360226 & 9939782 \\
\hline
\end{tabular}

Source: Travel Biz. Monitor 2012

\section{References}

[1] Anoop K. R, (2005), "Innovations In Natural Resource Management - A Case Study From Periyar Tiger Reserve, Kerala", under the supervision of Shri. Saurabh Gupta, IFS, Indira Gandhi National Forest Academy.

[2] Ansari, A.A., \& Gupta Vishal, (2006), "Changing Paradigm in Tourism Industry".

[3] Cater, Erlet. (1993), "Ecotourism in the third world: problems for sustainable tourism development. Tourism Management". http://dx.doi.org/10.1016/0261-5177(93)90040-R

[4] Cohen, Judy; Richardson, John. (1995), "Nature tourism vs. incompatible industries: mega-marketing the ecological environment to ensure the economic future of nature tourism". Journal of Travel and Tourism Marketing. http://dx.doi.org/10.1300/J073v04n02_10

[5] Gossling, Stefan, (1999), "Ecotourism: a means to safeguard biodiversity and ecosystem functions. Ecological Economics". http://dx.doi.org/10.1016/S0921-8009 (99)00012-9.

[6] Henry, I.P \& Jackson, G.A.M. (1996), "Sustainability of management processes and tourism products and contexts, Journal of Sustainable Tourism". http://dx.doi.org/10.1080/09669589608667256.
[7] Kline D. Jeffrey, (2001), "Tourism and Natural Resource Management: A General Overview of Research and issues", General Technical Report PNW-GTR-506, United States Department of Agriculture (USDA).

[8] Laarman, Jan G.; Sedjo, Roger A. (1992), "Global forests: issues for six billion people. New York: McGraw-Hill".

[9] Mason, P. J. L. (2005). Tourism, Environment and development. East Bourn: Manor Park Press.

[10]Mekvan, A.K. \& Dr. A.A. Ansari, (2006), "Human Resource \& Marketing Strategy in Tourism With reference to Saputara Hill Station of S. Gujarat".

[11]Robinson, H. (1976), "A Geography of Tourism", Aspect Geographies.

[12]Satish Babu, A. (1998), "Tourism Development in India" (A Case Study).

[13]Seidl, Andrew (1994), "Ecotourism: reworking the concepts of supply and demand".

[14] Shukla P. \& Ansari A.A., (2013), "Role of Tourism Industry in Employment Generation in Gujarat: A Geographic Assessment", Published in International Journal of Research in Humanities, Arts and Literature (IJRHAL), vol.1, issue 2, July 2013, 1-8.

[15]Wood, Megan Epler (1993), "Ecotourism guidelines for nature tour operators", North Bennington, VT: Ecotourism Society. 